Article

\title{
Eating Speed Is Associated with the Presence of Sarcopenia in Older Patients with Type 2 Diabetes: A Cross-Sectional Study of the KAMOGAWA-DM Cohort
}

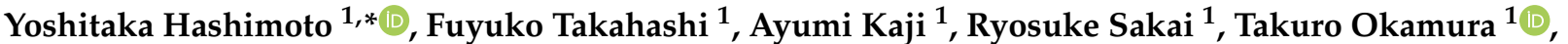 \\ Noriyuki Kitagawa ${ }^{1,2} \oplus$, Hiroshi Okada ${ }^{1,3}{ }^{\oplus}$, Naoko Nakanishi $^{1}$, Saori Majima ${ }^{1}$, Takafumi Senmaru ${ }^{1}\left({ }^{1}\right.$, \\ Emi Ushigome $^{1}{ }^{(D}$, Mai Asano ${ }^{1}$, Masahide Hamaguchi ${ }^{1}\left(\mathbb{D}\right.$, Masahiro Yamazaki $^{1}$ and Michiaki Fukui $^{1}$ (D) \\ 1 Department of Endocrinology and Metabolism, Graduate School of Medical Science, \\ Kyoto Prefectural University of Medicine, 465, Kajii-cho, Kawaramachi-Hirokoji, Kamigyo-ku, \\ Kyoto 602-8566, Japan; fuyuko-t@koto.kpu-m.ac.jp (F.T.); kaji-a@koto.kpu-m.ac.jp (A.K.); \\ sakaryo@koto.kpu-m.ac.jp (R.S.); d04sm012@koto.kpu-m.ac.jp (T.O.); nori-kgw@koto.kpu-m.ac.jp (N.K.); \\ conti@koto.kpu-m.ac.jp (H.O.); naoko-n@koto.kpu-m.ac.jp (N.N.); saori-m@koto.kpu-m.ac.jp (S.M.); \\ semmarut@koto.kpu-m.ac.jp (T.S.); emis@koto.kpu-m.ac.jp (E.U.); maias@koto.kpu-m.ac.jp (M.A.); \\ mhama@koto.kpu-m.ac.jp (M.H.); masahiro@koto.kpu-m.ac.jp (M.Y.); michiaki@koto.kpu-m.ac.jp (M.F.) \\ 2 Department of Diabetology, Kameoka Municipal Hospital, 1-1 Noda, Shinochoshino, Kyoto 621-8585, Japan \\ 3 Department of Diabetes and Endocrinology, Matsushita Memorial Hospital, 5-55 Sotojima-cho, \\ Moriguchi 570-8540, Japan \\ * Correspondence: y-hashi@koto.kpu-m.ac.jp
}

check for updates

Citation: Hashimoto, Y.; Takahashi, F.; Kaji, A.; Sakai, R.; Okamura, T.; Kitagawa, N.; Okada, H.; Nakanishi, N.; Majima, S.; Senmaru, T.; et al. Eating Speed Is Associated with the Presence of Sarcopenia in Older Patients with Type 2 Diabetes: A Cross-Sectional Study of the KAMOGAWA-DM Cohort. Nutrients 2022, 14, 759. https://doi.org/10.3390/ nu14040759

Academic Editor: Karin Bammann

Received: 20 January 2022

Accepted: 8 February 2022

Published: 11 February 2022

Publisher's Note: MDPI stays neutral with regard to jurisdictional claims in published maps and institutional affiliations.

Copyright: (C) 2022 by the authors. Licensee MDPI, Basel, Switzerland. This article is an open access article distributed under the terms and conditions of the Creative Commons Attribution (CC BY) license (https:// creativecommons.org/licenses/by/ $4.0 /)$.

\begin{abstract}
To determine the relationship between eating speed and the presence of sarcopenia in older patients with type 2 diabetes (T2D), in this cross-sectional study, patient eating speeds were classified as "fast-", "normal-" and "slow-speed eating." A multifrequency impedance analyzer was used to evaluate patient body compositions. Sarcopenia was defined as having both low muscle strength, a handgrip strength $<28 \mathrm{~kg}$ for men and $<18 \mathrm{~kg}$ for women, and low skeletal muscle mass as a skeletal muscle mass index $<7.0 \mathrm{~kg} / \mathrm{m}^{2}$ for men and $<5.7 \mathrm{~kg} / \mathrm{m}^{2}$ for women. Among 239 individuals, the frequencies of fast-, normal-, and slow-speed eating were $47.3 \%, 32.2 \%$, and $20.5 \%$, respectively; and the prevalence of sarcopenia was $15.9 \%$. Patients with a slow eating speed had greater prevalence of low skeletal muscle mass, low muscle strength, and sarcopenia than those with a fast or normal eating speed. After adjusting for covariates, compared to slow eaters, the odds ratio of having sarcopenia among fast- and normal-speed eaters was 0.31 [95\% CI: 0.12-0.80] and 0.18 [95\% CI: 0.06-0.53], respectively. Having a slow eating speed is associated with a heightened risk of sarcopenia in older patients with T2D.
\end{abstract}

Keywords: eating speed; diet; muscle mass; sarcopenia; diabetes

\section{Introduction}

The number of older patients with type 2 diabetes (T2D) has grown in recent years [1,2] and is forecasted to accelerate over the next few decades [3], owing to people living longer [4] and an increase in the prevalence of T2D within the general population [5]. A plethora of microvascular and macrovascular complications have been documented to emerge following the diagnosis of T2D in older individuals, one of the newest being sarcopenia $[2,6]$, an age-related degeneration of skeletal muscle that raises the likelihood of early mortality $[7,8]$.

Heeding this, the identification of risk factors for sarcopenia is critical for improving future prognoses. Two meta-analyses published last year revealed that among patients with T2D, increasing age, being male, or having hyperglycemia, osteoporosis, excessive visceral fat mass, diabetic nephropathy, T2D for a long duration, or high levels of C-reactive protein was associated significantly with an elevated risk of developing sarcopenia $[9,10]$. The 
contribution of one factor that remains to be fully clarified, however, is that of a person's dietary behavior.

Concerning consumption patterns, our team and several others have reported previously that low intakes of energy, proteins, vitamins B1, B12, and D, and omega-3 fatty acids augmented the chances of sarcopenia in older patients with T2D [11-16]. Eating speed, on the other hand, has attracted little attention to our knowledge, to date, even though there is compelling evidence to suggest that it exerts a prominent influence on the pathogenesis of the aforementioned disease. In particular, research shows that eating fast is connected to high energy intake [17] and a high body weight [18], which in turn may help attenuate the wasting effects of sarcopenia. For this cross-sectional investigation, we evaluated the relationship between eating speed and the presence of sarcopenia in older patients with T2D, hypothesizing that eating speed would be inversely associated with the presence of sarcopenia.

\section{Materials and Methods}

\subsection{Study Participants}

Individuals in this study were outpatients of Kyoto Prefectural University of Medicine Hospital (Kyoto, Japan) or Kameoka Municipal Hospital (Kameoka, Japan) and part of the KAMOGAWA-DM cohort, who have received ongoing assessments since 2014 by our group to yield insights into the history and progression of T2D [19]. Eligibility criteria consisted of having T2D and providing written informed consent to participate in the study; exclusion criteria consisted of not having T2D, using steroids, being under 60 years of age, or having medical charts that lacked data on handgrip strength, body composition, and/or habitual dietary intakes. The study was approved by the ethics committee of Kyoto Prefectural University of Medicine (No. RBMR-E-466-5) and was conducted in accordance with the Declaration of Helsinki.

\subsection{Data Collection}

A standardized questionnaire was used to gather data on each patient's duration of T2D, and smoking and exercise habits (i.e., frequency of playing sports on a weekly basis). (See Supplementary Materials) According to this information, patients were classified as non- or current smokers, and non- or regular venous blood draws took place after the patients had fasted overnight to ascertain their fasting plasma glucose and hemoglobin A1c levels. The estimated glomerular filtration rate (eGFR; $\mathrm{mL} / \mathrm{min} / 1.73 \mathrm{~m}^{2}$ ) was calculated by the Japanese Society of Nephrology equation [20] and eGFR under $30 \mathrm{~mL} / \mathrm{min} / 1.73 \mathrm{~m}^{2}$ were defined as chronic kidney diseases (CKD) stage $\geq 4$ [21]. Past medical histories regarding heart diseases, including angina, coronary heart disease, heart failure, prior acute myocardial infarction, stroke (ischemic or hemorrhagic), and cancers, were obtained from electronic medical records. Data on medications for T2D (e.g., insulin, glucagon-like peptide-1, antagonist sodium-glucose cotransporter- 2 inhibitors, and steroids) were also obtained from medical records.

\subsection{Assessments of Eating Speed and Habitual Dietary Intakes}

The brief-type self-administered diet history questionnaire [22] was employed to assess patient eating speed and habitual dietary intakes of 58 foods and beverages over the past month. Eating speed was evaluated by the following statements: for the former, the descriptors "very fast", " a little fast", "normal", "a little slow", or "very slow" were selected by the participants to characterize their eating speed, and then this information was used to classify the participants as "fast-speed eating", "normal-speed eating", or "slow-speed eating" [23]. Regarding the last, we obtained data on each participant's nutrient intake and then calculated their total energy intake by dividing the total energy intake by ideal body weight (kcal/IBW/day) [23]. Carbohydrate (\% energy), protein (\% energy), and fat (\% energy) intakes were calculated by multiplying the carbohydrate intake ( $\mathrm{g} /$ day) by $4(\mathrm{kcal} / \mathrm{g})$ and dividing that by the total energy intake (kcal/day), multiplying the protein 
intake (g/day) by 4 (kcal/g) and dividing that by the total energy intake (kcal/day), and multiplying the fat intake (g/day) by $9(\mathrm{kcal} / \mathrm{g})$ and dividing that by the total energy intake (kcal/day), respectively.

\subsection{Assessment of Sarcopenia}

InBody 720 (InBody Japan, Tokyo, Japan), a multifrequency impedance body composition analyzer with accuracy comparable to dual-energy X-ray absorptiometry [24], was used to evaluate body composition. Briefly, the body weight $(\mathrm{kg})$ and appendicular muscle mass $(\mathrm{kg})$ were measured by this analyzer, and then the body mass index (BMI, $\mathrm{kg} / \mathrm{m}^{2}$ ) or skeletal muscle mass index $\left(\mathrm{kg} / \mathrm{m}^{2}\right)$ was calculated by dividing the body weight $(\mathrm{kg})$ or appendicular muscle mass $(\mathrm{kg})$, respectively, by height squared $\left(\mathrm{m}^{2}\right)$.

A handgrip dynamometer (Smedley, Takei Scientific Instruments Co., Ltd., Niigata, Japan) evaluated patient handgrip strength, and the maximum value of handgrip strength for both hands was used in our analysis.

Low muscle strength was defined as having a handgrip strength $<28 \mathrm{~kg}$ for men and $<18 \mathrm{~kg}$ for women; low skeletal muscle mass was defined as having a skeletal muscle mass index $<7.0 \mathrm{~kg} / \mathrm{m}^{2}$ for men and $<5.7 \mathrm{~kg} / \mathrm{m}^{2}$ for women; sarcopenia was defined as having both low muscle strength and low skeletal muscle mass [25].

\subsection{Statistical Analyses}

We used JMP 13.2 software (SAS, Cary, NC, USA) for statistical analyses and considered $p<0.05$ as statistically significant. Continuous variables were described as the mean (standard deviation) or median (1st quartile-3rd quartile), and categorical variables were described as \% (number). Differences in variables of interest between the created groups were evaluated by one-way analysis of variance and the Tukey-Kramer test or Kruskal-Wallis test and Steel-Dwass test for continues variables, and a chi-squared test for categorized variables. Effects of eating speed on the presence of low muscle strength, low skeletal muscle mass, and sarcopenia were evaluated using logistic regressions. Factors of age, sex, insulin usage, smoking, exercise, total energy intakes (kcal/IBW/day), history of cancer, history of heart diseases and CKD stage $\geq 4$ were considered to be independent variables.

\section{Results}

In total, 563 individuals were enrolled in this study, though 324 were found to be ineligible; thus, this rendered a final number of 239 participants (Figure 1).

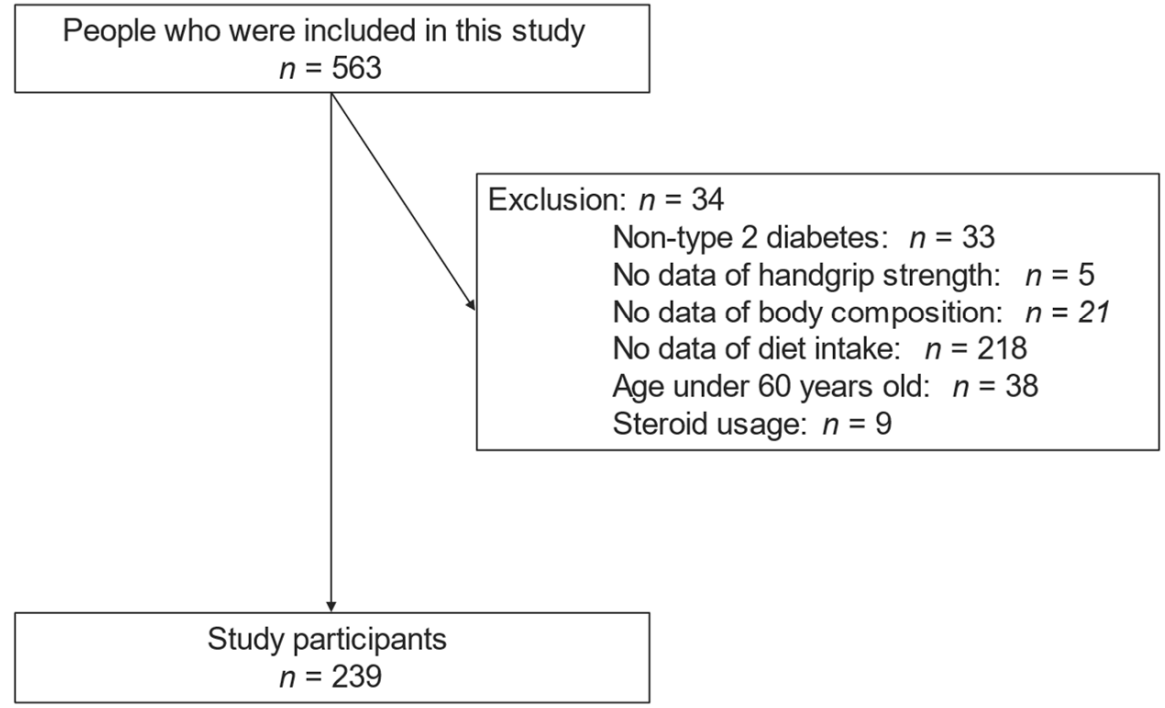

Figure 1. Inclusion and exclusion flow. 
Clinical characteristics of the participants are shown in Table 1. Their mean age and BMI were 71.6 (6.3) years and $23.6(3.5) \mathrm{kg} / \mathrm{m}^{2}$, respectively. According to the questionnaire, the frequency of fast, normal, and slow eating speeds was $47.3 \%, 32.2 \%$, and $20.5 \%$, respectively. From the body composition analyzer, the prevalence of low skeletal muscle mass, low muscle strength, and sarcopenia was $28.4 \%, 29.3 \%$, and $15.9 \%$, respectively.

Table 1. Clinical characteristics of study participants.

\begin{tabular}{|c|c|c|c|c|c|}
\hline & $\begin{array}{c}\text { All } \\
n=239\end{array}$ & $\begin{array}{c}\text { Fast, } \\
n=113\end{array}$ & $\begin{array}{c}\text { Normal, } \\
n=77\end{array}$ & $\begin{array}{c}\text { Slow, } \\
n=49\end{array}$ & $p$ \\
\hline Age, years & $71.6(6.2)$ & $70.7(6.2)$ & $72.1(6.2)$ & $73.0(6.0)$ & 0.075 \\
\hline Men, \% (n) & $58.6 \%(140)$ & $60.2 \%(68)$ & $62.3 \%(48)$ & $49.0 \%(24)$ & 0.297 \\
\hline Duration of diabetes, years & $18.4(11.5)$ & $17.9(10.8)$ & $18.8(13.1)$ & $19.1(10.7)$ & 0.776 \\
\hline Family history of diabetes, \% (n) & $41.8 \%(100)$ & $46.0 \%(52)$ & $28.6 \%(22)$ & $53.1 \%(26)$ & 0.012 \\
\hline Height, cm & $160.7(8.6)$ & $161.4(8.6)$ & $161.3(8.1)$ & $158.0(9.1)$ & 0.048 \\
\hline Body weight, $\mathrm{kg}$ & $61.1(10.8)$ & $63.3(10.7)$ & $61.5(10.6)$ & $55.2(9.7) \dagger \ddagger$ & $<0.001$ \\
\hline Body mass index, $\mathrm{kg} / \mathrm{m}^{2}$ & $23.6(3.5)$ & $24.2(3.1)$ & $23.6(3.8)$ & $22.2(3.8)+\ddagger$ & 0.004 \\
\hline Appendicular muscle mass, $\mathrm{kg}$ & $17.8(4.0)$ & $18.5(4.1)$ & $18.1(3.8)$ & $15.8(3.7)^{\dagger \ddagger}$ & 0.001 \\
\hline Skeletal muscle mass index, $\mathrm{kg} / \mathrm{m}^{2}$ & $6.8(1.0)$ & $7.0(1.0)$ & $6.9(1.1)$ & $6.2(0.9)^{\dagger \ddagger}$ & $<0.001$ \\
\hline Low skeletal muscle mass, \% (n) & $28.4 \%(68)$ & $21.2 \%(24)$ & $24.7 \%(19)$ & $51.0 \%(25)$ & $<0.001$ \\
\hline Handgrip strength, kg & $26.5(8.3)$ & $27.9(8.7)$ & $27.1(7.2)$ & $22.4(7.7) \dagger \ddagger$ & $<0.001$ \\
\hline Low muscle strength, \% $(n)$ & $29.3 \%(70)$ & $22.1 \%(25)$ & $24.7 \%(19)$ & $53.1 \%(26)$ & $<0.001$ \\
\hline Presence of sarcopenia, \% $(n)$ & $15.9 \%(38)$ & $12.4 \%(14)$ & $10.4 \%(8)$ & $32.7 \%(16)$ & 0.001 \\
\hline Insulin, $\%(n)$ & $23.5 \%(56)$ & $23.2 \%(26)$ & $23.4 \%(18)$ & $24.5 \%(12)$ & 0.984 \\
\hline GLP-1 antagonist, \% (n) & $8.4 \%(20)$ & $12.5 \%(14)$ & $5.2 \%(4)$ & $4.1 \%(2)$ & 0.097 \\
\hline SGLT2 inhibitor, \% (n) & $16.8 \%(40)$ & $22.3 \%(25)$ & $11.7 \%(9)$ & $12.2 \%(6)$ & 0.100 \\
\hline Smoker, \% (n) & $13.4 \%(32)$ & $15.9 \%(18)$ & $10.4 \%(8)$ & $12.2 \%(6)$ & 0.527 \\
\hline Exerciser, \% (n) & $50.6 \%(121)$ & $51.3 \%(58)$ & $52.0 \%(40)$ & $46.9 \%(23)$ & 0.843 \\
\hline History of cancer, \% $(n)$ & $22.2 \%(53)$ & $24.8 \%(28)$ & $36.4(28)$ & $30.6(15)$ & 0.227 \\
\hline History of heart diseases, $\%(n)$ & $29.7 \%(71)$ & $21.2(24)$ & $23.4 \%(18)$ & $22.5 \%(11)$ & 0.940 \\
\hline CKD stage $\geq 4, \%(n)$ & $4.6 \%(11)$ & $0.9 \%(1)$ & $9.1 \%(7)$ & $6.3 \%(3)$ & 0.025 \\
\hline $\mathrm{HbA} 1 \mathrm{c}, \mathrm{mmol} / \mathrm{mol}$ & $54.3(8.4)$ & $54.9(8.6)$ & $53.8(8.7)$ & $53.9(7.4)$ & 0.683 \\
\hline $\mathrm{HbA} 1 \mathrm{c}, \%$ & $7.1(0.8)$ & $7.2(0.8)$ & $7.1(0.8)$ & $7.1(0.7)$ & 0.683 \\
\hline Plasma glucose, $\mathrm{mmol} / \mathrm{L}$ & $8.1(2.3)$ & $8.0(2.1)$ & $8.1(2.4)$ & $8.3(2.6)$ & 0.678 \\
\hline Total energy intake, kcal/day & $1778(666)$ & $1765(649)$ & $1849(714)$ & $1699(627)$ & 0.453 \\
\hline Total energy intake, kcal/kg IBW/day & $31.3(11.7)$ & 30.7 (10.9) & $32.6(13.0)$ & $30.8(11.6)$ & 0.523 \\
\hline Protein intake, g/day & $75.9(34.7)$ & $74.8(30.1)$ & $81.4(37.0)$ & $69.8(29.5)$ & 0.130 \\
\hline Protein intake, \% Energy & $17.1(3.5)$ & $17.1(3.5)$ & $17.5(3.6)$ & $16.4(3.1)$ & 0.173 \\
\hline Fat intake, g/day & $57.6(25.3)$ & $56.7(24.1)$ & $59.4(26.2)$ & $56.6(27.1)$ & 0.739 \\
\hline Fat intake, \% Energy & $29.2(6.3)$ & $29.0(6.5)$ & $29.1(6.4)$ & $29.6(5.7)$ & 0.862 \\
\hline Carbohydrate intake, g/day & $221.7(86.5)$ & $223.3(90.5)$ & $229.6(86.9)$ & $205.5(75.2)$ & 0.303 \\
\hline Carbohydrate intake, \% Energy & $50.3(8.7)$ & $50.7(9.1)$ & $50.4(8.2)$ & $49.3(8.6)$ & 0.623 \\
\hline Alcohol consumption, g/day & $0(0-2.4)$ & $0(0-2.9)$ & $0(0-0.2)$ & $0.1(0-9.9) \ddagger$ & 0.033 \\
\hline Dietary fiber intake, g/day & $12.6(5.4)$ & $12.4(5.4)$ & $13.3(5.6)$ & $12.2(5.2)$ & 0.416 \\
\hline
\end{tabular}

Data were expressed as mean (standard deviation), median (1st quartile-3rd quartile) or number (\%). Differences in variables of interest between the created groups were evaluated by one-way analysis of variance and the Tukey-Kramer test or Kruskal-Wallis test and Steel-Dwass test for continues variables, and a chi-squared test for categorized variables. GLP-1, glucagon-like peptide-1; SGLT, sodium-glucose cotransporter; CKD, chronic kidney disease; IBW, ideal body weight. $\uparrow, p<0.05$ vs. fast-speed eating and $\ddagger, p<0.05$ vs. normal-speed eating by Tukey-Kramer test.

Analyses showed that slow eaters had greater amounts of low skeletal muscle mass, low muscle strength, or sarcopenia than fast- or normal-speed eaters (Table 1 and Figure 2). No statistically significant differences in total energy or protein intakes were detected between the eating-speed groups, nor were there any significant effects of age or sex on the prevalence of low skeletal muscle mass, low muscle strength, or sarcopenia. 

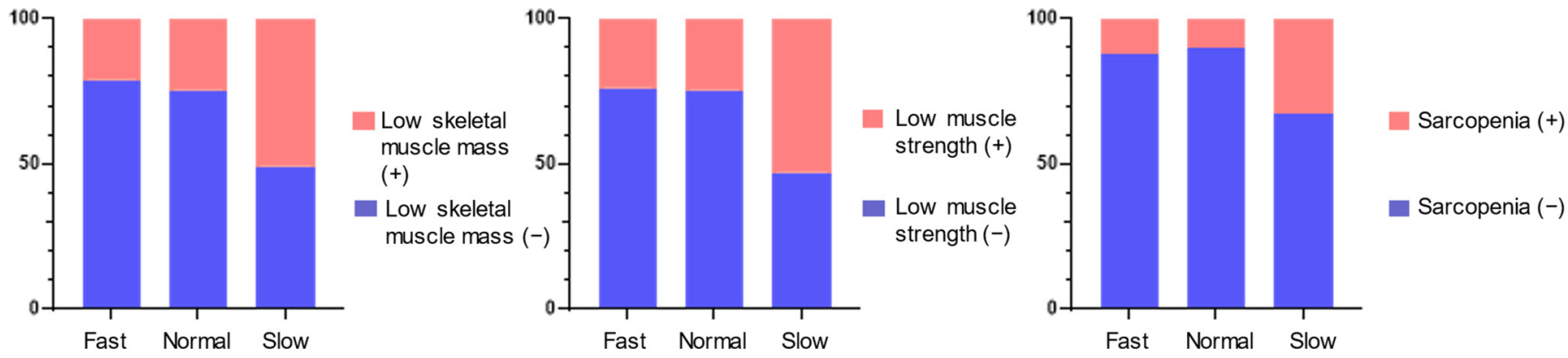

Figure 2. Proportions of low skeletal muscle mass, low muscle strength and sarcopenia among fast-, normal- and slow-speed eating groups.

Relationships between eating speed and the presence of low skeletal muscle mass, low muscle strength, or sarcopenia are shown in Table 2. After adjusting for covariates, compared to slow eaters, the odds ratio of having low skeletal muscle mass among fast- and normal-speed eaters was 0.27 [95\% confidence interval (CI): $0.12-0.57, p<0.001$ ] and 0.32 (95\% CI: $0.14-0.71, p=0.005)$, respectively; the odds ratio of having low muscle strength among fast- and normal-speed eaters was 0.28 (95\% CI: $0.12-0.65, p=0.003)$ and 0.22 (95\% CI: $0.09-0.57, p=0.002)$, respectively; and the odds ratio of having sarcopenia among the fast- and normal-speed eaters was 0.31 (95\% CI: $0.12-0.80, p=0.016)$ and 0.18 (95\% CI: $0.06-0.53, p=0.002)$, respectively (Model 4).

Table 2. Relationship between eating speed and the presence of sarcopenia.

\begin{tabular}{|c|c|c|c|c|c|c|c|c|}
\hline \multirow[b]{2}{*}{$\begin{array}{l}\text { The presence of low } \\
\text { muscle mass }\end{array}$} & \multicolumn{2}{|c|}{ Model 1} & \multicolumn{2}{|c|}{ Model 2} & \multicolumn{2}{|c|}{ Model 3} & \multicolumn{2}{|c|}{ Model 4} \\
\hline & $\begin{array}{l}\text { Odds ratio } \\
(95 \% \mathrm{CI})\end{array}$ & $p$ value & $\begin{array}{l}\text { Odds ratio } \\
(95 \% \mathrm{CI})\end{array}$ & $p$ value & $\begin{array}{l}\text { Odds ratio } \\
(95 \% \mathrm{CI})\end{array}$ & $p$ value & $\begin{array}{l}\text { Odds ratio } \\
(95 \% \mathrm{CI})\end{array}$ & $p$ value \\
\hline Age (year) & - & - & $\begin{array}{c}1.06 \\
(1.01-1.12)\end{array}$ & 0.011 & $\begin{array}{c}1.07 \\
(1.02-1.12)\end{array}$ & 0.009 & $\begin{array}{c}1.07 \\
(1.02-1.13)\end{array}$ & 0.009 \\
\hline Men & - & - & $\begin{array}{c}1.09 \\
(0.60-2.01)\end{array}$ & 0.770 & $\begin{array}{c}1.22 \\
(0.65-2.28)\end{array}$ & 0.537 & $\begin{array}{c}1.23 \\
(0.65-2.32)\end{array}$ & 0.528 \\
\hline Insulin usage & - & - & - & - & $\begin{array}{c}1.43 \\
(0.72-2.87)\end{array}$ & 0.303 & $\begin{array}{c}1.49 \\
(0.75-2.98)\end{array}$ & 0.259 \\
\hline Smoking & - & - & - & - & $\begin{array}{c}0.82 \\
(0.31-2.14)\end{array}$ & 0.681 & $\begin{array}{c}0.77 \\
(0.29-2.03)\end{array}$ & 0.593 \\
\hline Exercise & - & - & - & - & $\begin{array}{c}1.66 \\
(0.91-3.05)\end{array}$ & 0.106 & $\begin{array}{c}1.64 \\
(0.89-3.03)\end{array}$ & 0.116 \\
\hline $\begin{array}{c}\text { Total energy intake }(\mathrm{kcal} / \mathrm{kg} \\
\text { IBW / day) }\end{array}$ & - & 一 & - & - & $\begin{array}{c}0.97 \\
(0.94-1.01)\end{array}$ & 0.092 & $\begin{array}{c}0.97 \\
(0.94-1.01)\end{array}$ & 0.089 \\
\hline CKD stage $\geq 4$ & - & - & - & - & - & - & $\begin{array}{c}0.68 \\
(0.16-2.88)\end{array}$ & 0.600 \\
\hline History of cancer & - & - & - & - & - & - & $\begin{array}{c}0.73 \\
(0.34-1.56)\end{array}$ & 0.415 \\
\hline History of heart diseases & - & - & - & - & - & - & $\begin{array}{c}0.84 \\
(0.42-1.68)\end{array}$ & 0.625 \\
\hline \multicolumn{9}{|l|}{ Eating speed } \\
\hline Fast & $\begin{array}{c}0.26 \\
(0.13-0.53)\end{array}$ & $<0.001$ & $\begin{array}{c}0.28 \\
(0.14-0.59)\end{array}$ & $<0.001$ & $\begin{array}{c}0.27 \\
(0.13-0.56)\end{array}$ & $<0.001$ & $\begin{array}{c}0.27 \\
(0.12-0.57)\end{array}$ & $<0.001$ \\
\hline Normal & $\begin{array}{c}0.31 \\
(0.15-0.67)\end{array}$ & 0.003 & $\begin{array}{c}0.32 \\
(0.15-0.69)\end{array}$ & 0.004 & $\begin{array}{c}0.31 \\
(0.14-0.68)\end{array}$ & 0.004 & $\begin{array}{c}0.32 \\
(0.14-0.71)\end{array}$ & 0.005 \\
\hline Slow & Reference & - & Reference & - & Reference & - & Reference & - \\
\hline
\end{tabular}


Table 2. Cont.

\begin{tabular}{|c|c|c|c|c|c|c|c|c|}
\hline \multirow{2}{*}{$\begin{array}{l}\text { The presence of low } \\
\text { handgrip strength }\end{array}$} & \multicolumn{2}{|c|}{ Model 1} & \multicolumn{2}{|c|}{ Model 2} & \multicolumn{2}{|c|}{ Model 3} & \multicolumn{2}{|c|}{ Model 4} \\
\hline & $\begin{array}{l}\text { Odds ratio } \\
(95 \% \mathrm{CI})\end{array}$ & $p$ value & $\begin{array}{l}\text { Odds ratio } \\
(95 \% \text { CI })\end{array}$ & $p$ value & $\begin{array}{l}\text { Odds ratio } \\
(95 \% \mathrm{CI})\end{array}$ & $p$ value & $\begin{array}{l}\text { Odds ratio } \\
(95 \% \mathrm{CI})\end{array}$ & $p$ value \\
\hline Age (year) & - & - & $\begin{array}{c}1.18 \\
(1.12-1.25)\end{array}$ & $<0.001$ & $\begin{array}{c}1.19 \\
(1.12-1.26)\end{array}$ & $<0.001$ & $\begin{array}{c}1.19 \\
(1.12-1.27)\end{array}$ & $<0.001$ \\
\hline Men & - & - & $\begin{array}{c}0.58 \\
(0.30-1.11)\end{array}$ & 0.099 & $\begin{array}{c}0.64 \\
(0.33-1.25)\end{array}$ & 0.191 & $\begin{array}{c}0.59 \\
(0.29-1.18)\end{array}$ & 0.138 \\
\hline Insulin usage & - & - & - & - & $\begin{array}{c}1.85 \\
(0.87-3.95)\end{array}$ & 0.111 & $\begin{array}{c}1.88 \\
(0.86-4.09)\end{array}$ & 0.112 \\
\hline Smoking & - & - & - & - & $\begin{array}{c}0.70 \\
(0.22-2.19)\end{array}$ & 0.535 & $\begin{array}{c}0.65 \\
(0.20-2.15)\end{array}$ & 0.482 \\
\hline Exercise & - & - & - & - & $\begin{array}{c}1.58 \\
(0.82-3.06)\end{array}$ & 0.175 & $\begin{array}{c}1.70 \\
(0.86-3.37)\end{array}$ & 0.129 \\
\hline $\begin{array}{c}\text { Total energy intake (kcal/kg } \\
\text { IBW/day) }\end{array}$ & - & - & - & - & $\begin{array}{c}1.00 \\
(0.97-1.03)\end{array}$ & 0.761 & $\begin{array}{c}1.00 \\
(0.97-1.03)\end{array}$ & 0.923 \\
\hline CKD stage $\geq 4$ & - & - & - & - & - & - & $\begin{array}{c}4.37 \\
(1.00-19.1)\end{array}$ & 0.005 \\
\hline History of cancer & - & - & - & - & - & - & $\begin{array}{c}0.37 \\
(0.15-0.92)\end{array}$ & 0.033 \\
\hline History of heart diseases & - & - & - & - & - & - & $\begin{array}{c}1.40 \\
(0.67-2.91)\end{array}$ & 0.372 \\
\hline \multicolumn{9}{|l|}{ Eating speed } \\
\hline Fast & $\begin{array}{c}0.25 \\
(0.12-0.51)\end{array}$ & $<0.001$ & $\begin{array}{c}0.28 \\
(0.13-0.62)\end{array}$ & 0.002 & $\begin{array}{c}0.27 \\
(0.12-0.61)\end{array}$ & 0.002 & $\begin{array}{c}0.28 \\
(0.12-0.65)\end{array}$ & 0.003 \\
\hline Normal & $\begin{array}{c}0.29 \\
(0.14-0.62)\end{array}$ & 0.002 & $\begin{array}{c}0.28 \\
(0.12-0.67)\end{array}$ & 0.004 & $\begin{array}{c}0.27 \\
(0.11-0.64)\end{array}$ & 0.003 & $\begin{array}{c}0.22 \\
(0.09-0.57)\end{array}$ & 0.002 \\
\hline Slow & Reference & - & Reference & - & Reference & - & Reference & - \\
\hline \multirow[b]{2}{*}{ The presence of sarcopenia } & \multicolumn{2}{|c|}{ Model 1} & \multicolumn{2}{|c|}{ Model 2} & \multicolumn{2}{|c|}{ Model 3} & \multicolumn{2}{|c|}{ Model 4} \\
\hline & $\begin{array}{c}\text { Odds ratio } \\
(95 \% \text { CI) }\end{array}$ & $p$ value & $\begin{array}{c}\text { Odds ratio } \\
\text { (95\% CI) }\end{array}$ & $p$ value & $\begin{array}{c}\text { Odds ratio } \\
(95 \% \mathrm{CI})\end{array}$ & $p$ value & $\begin{array}{c}\text { Odds ratio } \\
(95 \% \mathrm{CI})\end{array}$ & $p$ value \\
\hline Age (year) & - & - & $\begin{array}{c}1.16 \\
(1.09-1.24)\end{array}$ & $<0.001$ & $\begin{array}{c}1.18 \\
(1.10-1.26)\end{array}$ & $<0.001$ & $\begin{array}{c}1.17 \\
(1.09-1.26)\end{array}$ & $<0.001$ \\
\hline Men & - & - & $\begin{array}{c}1.11 \\
(0.51-2.43)\end{array}$ & 0.796 & $\begin{array}{c}1.29 \\
(0.57-2.90)\end{array}$ & 0.539 & $\begin{array}{c}1.19 \\
(0.52-2.73)\end{array}$ & 0.681 \\
\hline Insulin usage & - & - & - & - & $\begin{array}{c}1.53 \\
(0.63-3.75)\end{array}$ & 0.351 & $\begin{array}{c}1.63 \\
(0.65-4.04)\end{array}$ & 0.295 \\
\hline Smoking & - & - & - & - & $\begin{array}{c}0.76 \\
(0.19-2.97)\end{array}$ & 0.693 & $\begin{array}{c}0.67 \\
(0.17-2.72)\end{array}$ & 0.579 \\
\hline Exercise & - & - & - & - & $\begin{array}{c}2.35 \\
(1.04-5.31)\end{array}$ & 0.040 & $\begin{array}{c}2.54 \\
(1.09-5.94)\end{array}$ & 0.032 \\
\hline $\begin{array}{c}\text { Total energy intake (kcal/kg } \\
\text { IBW/day) }\end{array}$ & - & - & - & - & $\begin{array}{c}0.99 \\
(0.95-1.03)\end{array}$ & 0.564 & $\begin{array}{c}0.99 \\
(0.95-1.03)\end{array}$ & 0.700 \\
\hline CKD stage $\geq 4$ & - & - & - & - & - & - & $\begin{array}{c}2.33 \\
(0.47-11.6)\end{array}$ & 0.299 \\
\hline History of cancer & - & - & - & - & - & - & $\begin{array}{c}0.36 \\
(0.12-1.10)\end{array}$ & 0.072 \\
\hline History of heart diseases & - & - & - & - & - & - & $\begin{array}{c}1.29 \\
(0.56-3.01)\end{array}$ & 0.550 \\
\hline \multicolumn{9}{|l|}{ Eating speed } \\
\hline Fast & $\begin{array}{c}0.29 \\
(0.13-0.66)\end{array}$ & 0.003 & $\begin{array}{c}0.34 \\
(0.14-0.81)\end{array}$ & 0.015 & $\begin{array}{c}0.31 \\
(0.12-0.76)\end{array}$ & 0.010 & $\begin{array}{c}0.31 \\
(0.12-0.80)\end{array}$ & 0.016 \\
\hline Normal & $\begin{array}{c}0.24 \\
(0.09-0.62)\end{array}$ & 0.003 & $\begin{array}{c}0.22 \\
(0.08-0.60)\end{array}$ & 0.003 & $\begin{array}{c}0.19 \\
(0.07-0.55)\end{array}$ & 0.002 & $\begin{array}{c}0.18 \\
(0.06-0.53)\end{array}$ & 0.002 \\
\hline Slow & Reference & - & Reference & - & Reference & - & Reference & - \\
\hline
\end{tabular}

Model 1 was the unadjusted model, model 2 was adjusted for age and sex, model 3 was adjusted for model 2 and insulin usage, smoking, exercise and total energy intake, and model 4 was adjusted for model 3 and CKD stage $\geq 4$, history of cancer and history of heart diseases. CKD, chronic kidney disease; IBW, ideal body weight.

\section{Discussion}

Our study demonstrated, in line with the hypothesis, that a slow eating speed is associated with a heightened risk of low skeletal muscle mass, low muscle strength, and sarcopenia in older patients with T2D.

Earlier research has revealed that eating speed is strongly connected to body weight: fast eating is often tied to a high BMI and its associated comorbidities [18,23,26-29], whereas 
slow eating is related to a lean weight status [30]. Reasons for this phenomenon are not entirely clear, although it is feasible that fast eating engenders greater energy intake [31], whereas slow eating does the opposite [32]. Chewing food well over time is known to increase both the release of neuronal histamine and the postprandial response of hormones such as ghrelin, glucagon-like peptide-1, and peptide $Y Y$, which are involved in the stimulation of the satiety center and sympathetic nervous system [33], and the regulation of hunger, satiety, and energy intake, respectively [34]. In this study, we found that slow eaters had a lower BMI than those in the two other groups, yet dietary intake was comparable across all eating, whereas there were no relationship speed classifications. Discrepancies between our data and those of previous investigations could be due to reporting errors, as individuals with obesity tend to underestimate their dietary intakes [31,35]. Nevertheless, and more importantly here, our collective findings suggest that reduced intake is not implicated in the association between slow eating and sarcopenia; therefore, other factors are likely at play. To this point, several scholars have noticed a close relationship between sarcopenia and oral function [36-40], indicating that this muscle disorder might be linked to slower-paced eating via impairments in swallowing.

The limitations of this study should be mentioned. First, it was cross-sectional in nature; thus, a causal relationship remains to be elucidated. Second, data on participant eating speeds were collected using a self-report questionnaire, which is a subjective assessment and not an objective one, and therefore, our outcomes should be interpreted with caution. Third, the number of the participants was relatively small and outpatient-only. However, the proportion of the presence of sarcopenia of $15.8 \%$ in this study, was almost same as the data of a recent metanalysis [41]. Fourth, we did not have the data of frequency of hospital admissions, which are associated with muscle loss [42]. Lastly, considering that all participants had T2D, it is possible that having a slow eating speed could be attributed more to advice from healthcare professionals than sarcopenia itself.

\section{Conclusions}

In conclusion, slow eating was found to be associated with an increased risk of sarcopenia in older patients with T2D. Current recommendations for the prevention of conditions such as obesity [18], metabolic syndrome [26] and nonalcoholic fatty liver disease [23] in patients with T2D include expressed eating speed, and, as such, stand in opposition to our findings that slow eating could be harmful in some cases. Presently, no clear strategy exists for shifting nutritional guidance from obesity and/or metabolic syndrome to sarcopenia in older people with T2D [43]. Henceforth, prospective explorations into mechanisms underlying the linkage between slow eating and sarcopenia and the direction of causality will inform the optimization of the overall management of T2D in older patients going forward.

Supplementary Materials: The following supporting information can be downloaded at: https: / www. mdpi.com/article/10.3390/nu14040759/s1, duration of T2D, and smoking and exercise habits questionnaire.

Author Contributions: Y.H. conceived and designed the study, acquired, analyzed, and interpreted the data, and wrote the manuscript. F.T. acquired and interpreted the data, and contributed to writing the manuscript. A.K. and R.S. conceived and designed the study, acquired the data, and contributed to the Discussion section of the manuscript. T.O., N.K., H.O., N.N., S.M., T.S., E.U. and M.A. acquired the data and contributed to the Discussion section of the manuscript. M.H. designed the study, acquired the data, and contributed to the Discussion section of the manuscript. M.Y. acquired the data and contributed to the Discussion section of the manuscript. M.F. conceived and designed the study, acquired and interpreted the data, and revised the manuscript. All authors have read and agreed to the published version of the manuscript.

Funding: This research received no external funding.

Institutional Review Board Statement: The study was approved by the ethics committee of Kyoto Prefectural University of Medicine (No. RBMR-E-466-5) and was conducted in accordance with the Declaration of Helsinki. 
Informed Consent Statement: Written informed consent to participate in the study.

Data Availability Statement: The data that support the findings of this study are available from the corresponding author, $\mathrm{YH}$, upon reasonable request.

Conflicts of Interest: Dr. Hashimoto reports grants and personal fees from Sanofi K.K., Novo Nordisk Pharma Ltd., Daiichi Sankyo Co., Ltd., and Mitsubishi Tanabe Pharma Corp. outside the submitted work. Dr. Senmaru has received personal fees from Astellas Pharma Inc., Sanofi K.K., Taisho Toyama Pharma Co., Ltd., Ono Pharma Co., Ltd., Eli Lilly Japan K.K., Kowa Pharma Co., Ltd., Kyowa Hakko Kirin Co., Ltd., Mitsubishi Tanabe Pharma Co., Takeda Pharma Co., Ltd., Kissei Pharma Co., Ltd., Novo Nordisk Pharma Ltd., and MSD K.K. outside the submitted work. Dr. Ushigome has received grant support from the Astellas Foundation for Research on Metabolic Disorders and the Japanese Study Group for Physiology and Management of Blood Pressure, donated fund Laboratory of Diabetes therapeutics is an endowment department, supported with an unrestricted grant from Ono Pharma Co., Ltd., and has received personal fees from Kowa Pharma Co., Ltd., Sumitomo Dainippon Pharma Co., Ltd., Kyowa Kirin Co., Ltd., MSD K.K., Nippon Boehringer Ingelheim Co., Ltd., AstraZeneca PLC, Daiichi Sankyo Co., Ltd., Astellas Pharma Inc., Mitsubishi Tanabe Pharma Corp., Novo Nordisk Pharma Ltd., Takeda Pharma Co., Ltd., and Taisho Toyama Pharma Co., Ltd. outside the submitted work. Dr. Hamaguchi reports grants from Novo Nordisk Pharma Ltd., Eli Lilly Japan K.K., Asahi Kasei Pharma, Nippon Boehringer Ingelheim Co., Ltd., Mitsubishi Tanabe Pharma Corp., Astellas Pharma Inc., Sanofi K.K., Takeda Pharma Co., Ltd., Kyowa Kirin Co., Ltd., Daiichi Sankyo Co., Ltd., and Sumitomo Dainippon Pharma Co., Ltd. outside the submitted work. Dr. Asano reports honoraria from Kowa Pharmaceutical Co., Ltd., AstraZeneca PLC, Ono Pharmaceutical Co., Ltd., Abbott Japan Co., Ltd., Novo Nordisk Pharma Ltd., and Sumitomo Dainippon Pharma Co., Ltd. Dr. Yamazaki reports personal fees from Kyowa Kirin Co., Ltd., AstraZeneca PLC, Kowa Pharma Co., Ltd., Takeda Pharma Co., Ltd., MSD K.K., Kowa Pharma Co., Ltd., Ono Pharma Co., Ltd., Sumitomo Dainippon Pharma Co., Ltd., and Daiichi Sankyo Co., Ltd. outside the submitted work. Prof. Fukui has received grants from Taisho Pharma Co., Ltd., Kowa Pharma Co., Ltd., Takeda Pharma Co., Ltd., Sanofi K.K., Daiichi Sankyo Co., Ltd., Eli Lilly Japan K.K., Tejin Pharma Ltd., Mitsubishi Tanabe Pharma Corp, Astellas Pharma Inc., Ono Pharma Co., Ltd., Abbott Japan Co., Ltd., Sanwa Kagagu Kenkyusho Co., Ltd., Terumo Corp., Novo Nordisk Pharma Ltd., Kyowa Kirin Co., Ltd., MSD K.K., Sumitomo Dainippon Pharma Co., Ltd., Kissei Pharma Co. Ltd., Nippon Chemiphar Co., Ltd., Johnson \& Johnson K.K. Medical Co., and Nippon Boehringer Ingelheim Co., Ltd., and has received honoraria from Novo Nordisk Pharma Ltd., Arkray, Inc., Sanofi K.K., Medtronic Japan Co., Ltd., Daiichi Sankyo Co., Ltd., Takeda Pharma Co., Ltd., Kissei Pharma Co., Ltd., Abbott Japan Co., Ltd., Teijin Pharma Ltd., Nipro Corp., MSD K.K., Kyowa Kirin Co., Ltd., Ono Pharma Co., Ltd., Bayer Yakuhin, Ltd., Sumitomo Dainippon Pharma Co., Ltd., Astellas Pharma Inc., Mitsubishi Tanabe Pharma Corp., Sanwa Kagaku Kenkyusho Co., Ltd., Kowa Pharma Co., Ltd., Taisho Pharma Co., Ltd., AstraZeneca K.K., Eli Lilly Japan K.K., Mochida Pharma Co., Ltd., and Nippon Boehringer Ingelheim Co., Ltd. outside the submitted work. The other authors have nothing to disclose.

\section{References}

1. Bradley, D. Type 2 Diabetes in the Elderly: Challenges in a Unique Patient Population. J. Geriatr. Med. Gerontol. 2016, 2, 14. [CrossRef] [PubMed]

2. Umegaki, H. Sarcopenia and frailty in older patients with diabetes mellitus. Geriatr. Gerontol. Int. 2016, 16, 293-299. [CrossRef] [PubMed]

3. American Diabetes Association. 12. Older Adults: Standards of Medical Care in Diabetes-2019. Diabetes Care 2019, 42, S139-S147. [CrossRef] [PubMed]

4. Meyer, A.C.; Drefahl, S.; Ahlbom, A.; Lambe, M.; Modig, K. Trends in life expectancy: Did the gap between the healthy and the ill widen or close? BMC Med. 2020, 18, 41. [CrossRef]

5. Khan, M.; Hashim, M.J.; King, J.K.; Govender, R.D.; Mustafa, H.; Al Kaabi, J. Epidemiology of Type 2 Diabetes—Global Burden of Disease and Forecasted Trends. J. Epidemiol. Glob. Health 2020, 10, 107-111. [CrossRef] [PubMed]

6. Liccini, A.; Malmstrom, T.K. Frailty and Sarcopenia as Predictors of Adverse Health Outcomes in Persons with Diabetes Mellitus. J. Am. Med. Dir. Assoc. 2016, 17, 846-851. [CrossRef]

7. Takahashi, F.; Hashimoto, Y.; Kaji, A.; Sakai, R.; Okamura, T.; Kitagawa, N.; Okada, H.; Nakanishi, N.; Majima, S.; Senmaru, T.; et al. Sarcopenia Is Associated with a Risk of Mortality in People with Type 2 Diabetes Mellitus. Front. Endocrinol. (Lausanne) 2021, 12, 783363. [CrossRef]

8. Miyake, H.; Kanazawa, I.; Tanaka, K.I.; Sugimoto, T. Low skeletal muscle mass is associated with the risk of all-cause mortality in patients with type 2 diabetes mellitus. Ther. Adv. Endocrinol. Metab. 2019, 10, 2042018819842971. [CrossRef] [PubMed] 
9. Ai, Y.; Xu, R.; Liu, L. The prevalence and risk factors of sarcopenia in patients with type 2 diabetes mellitus: A systematic review and meta-analysis. Diabetol. Metab. Syndr. 2021, 13, 93. [CrossRef] [PubMed]

10. Feng, L.; Gao, Q.; Hu, K.; Wu, M.; Wang, Z.; Chen, F.; Mei, F.; Zhao, L.; Ma, B. Prevalence and risk factors of sarcopenia in patients with diabetes: A meta-analysis. J. Clin. Endocrinol. Metab. 2021, in press. [CrossRef]

11. Yoshimura, Y.; Kamada, C.; Takahashi, K.; Kaimoto, T.; Iimuro, S.; Ohashi, Y.; Araki, A.; Umegaki, H.; Sakurai, T.; Ito, H.; et al. Relations of nutritional intake to age, sex and body mass index in Japanese elderly patients with type 2 diabetes: The Japanese Elderly Diabetes Intervention Trial. Geriatr. Gerontol. Int. 2012, 12 (Suppl. S1), 29-40. [CrossRef] [PubMed]

12. Rahi, B.; Morais, J.A.; Gaudreau, P.; Payette, H.; Shatenstein, B. Energy and protein intakes and their association with a decline in functional capacity among diabetic older adults from the NuAge cohort. Eur. J. Nutr. 2016, 55, 1729-1739. [CrossRef]

13. Takahashi, F.; Hashimoto, Y.; Kaji, A.; Sakai, R.; Kawate, Y.; Okamura, T.; Kondo, Y.; Fukuda, T.; Kitagawa, N.; Okada, H.; et al. Vitamin Intake and Loss of Muscle Mass in Older People with Type 2 Diabetes: A Prospective Study of the KAMOGAWA-DM Cohort. Nutrients 2021, 13, 2335. [CrossRef] [PubMed]

14. Kawano, R.; Takahashi, F.; Hashimoto, Y.; Okamura, T.; Miki, A.; Kaji, A.; Sakai, R.; Kitagawa, N.; Senmaru, T.; Majima, S.; et al. Short energy intake is associated with muscle mass loss in older patients with type 2 diabetes: A prospective study of the KAMOGAWA-DM cohort. Clin. Nutr. 2021, 40, 1613-1620. [CrossRef] [PubMed]

15. Okamura, T.; Hashimoto, Y.; Miki, A.; Kaji, A.; Sakai, R.; Iwai, K.; Osaka, T.; Ushigome, E.; Hamaguchi, M.; Yamazaki, M.; et al Reduced dietary omega-3 fatty acids intake is associated with sarcopenia in elderly patients with type 2 diabetes: A cross-sectional study of KAMOGAWA-DM cohort study. J. Clin. Biochem. Nutr. 2020, 66, 233-237. [CrossRef] [PubMed]

16. Okamura, T.; Miki, A.; Hashimoto, Y.; Kaji, A.; Sakai, R.; Osaka, T.; Hamaguchi, M.; Yamazaki, M.; Fukui, M. Shortage of energy intake rather than protein intake is associated with sarcopenia in elderly patients with type 2 diabetes: A cross-sectional study of the KAMOGAWA-DM cohort. J. Diabetes 2019, 11, 477-483. [CrossRef] [PubMed]

17. Teo, P.S.; van Dam, R.M.; Whitton, C.; Tan, L.W.L.; Forde, C.G. Association Between Self-Reported Eating Rate, Energy Intake, and Cardiovascular Risk Factors in a Multi-Ethnic Asian Population. Nutrients 2020, 12, 1080. [CrossRef] [PubMed]

18. Kolay, E.; Bykowska-Derda, A.; Abdulsamad, S.; Kaluzna, M.; Samarzewska, K.; Ruchala, M.; Czlapka-Matyasik, M. Self-Reported Eating Speed Is Associated with Indicators of Obesity in Adults: A Systematic Review and Meta-Analysis. Healthcare 2021, 9 , 1559. [CrossRef]

19. Sakai, R.; Hashimoto, Y.; Ushigome, E.; Miki, A.; Okamura, T.; Matsugasumi, M.; Fukuda, T.; Majima, S.; Matsumoto, S.; Senmaru, T.; et al. Late-night-dinner is associated with poor glycemic control in people with type 2 diabetes: The KAMOGAWADM cohort study. Endocr. J. 2018, 65, 395-402. [CrossRef]

20. Matsuo, S.; Imai, E.; Horio, M.; Yasuda, Y.; Tomita, K.; Nitta, K.; Yamagata, K.; Tomino, Y.; Yokoyama, H.; Hishida, A.; et al. Revised equations for estimated GFR from serum creatinine in Japan. Am. J. Kidney Dis. 2009, 53, 982-992. [CrossRef]

21. Chen, T.K.; Knicely, D.H.; Grams, M.E. Chronic Kidney Disease Diagnosis and Management: A Review. JAMA 2019, 322, 1294-1304. [CrossRef] [PubMed]

22. Kobayashi, S.; Honda, S.; Murakami, K.; Sasaki, S.; Okubo, H.; Hirota, N.; Notsu, A.; Fukui, M.; Date, C. Both comprehensive and brief self-administered diet history questionnaires satisfactorily rank nutrient intakes in Japanese adults. J. Epidemiol. 2012, 22, 151-159. [CrossRef]

23. Takahashi, F.; Hashimoto, Y.; Kawano, R.; Kaji, A.; Sakai, R.; Kawate, Y.; Okamura, T.; Ushigome, E.; Kitagawa, N.; Majima, S.; et al. Eating Fast Is Associated with Nonalcoholic Fatty Liver Disease in Men But Not in Women with Type 2 Diabetes: A Cross-Sectional Study. Nutrients 2020, 12, 2174. [CrossRef]

24. Kim, M.; Shinkai, S.; Murayama, H.; Mori, S. Comparison of segmental multifrequency bioelectrical impedance analysis with dual-energy X-ray absorptiometry for the assessment of body composition in a community-dwelling older population. Geriatr. Gerontol. Int. 2015, 15, 1013-1022. [CrossRef] [PubMed]

25. Chen, L.K.; Woo, J.; Assantachai, P.; Auyeung, T.W.; Chou, M.Y.; Iijima, K.; Jang, H.C.; Kang, L.; Kim, M.; Kim, S.; et al. Asian Working Group for Sarcopenia: 2019 Consensus Update on Sarcopenia Diagnosis and Treatment. J. Am. Med. Dir. Assoc. 2020, 21, 300-307.e2. [CrossRef] [PubMed]

26. Nanri, A.; Miyaji, N.; Kochi, T.; Eguchi, M.; Kabe, I.; Mizoue, T. Eating speed and risk of metabolic syndrome among Japanese workers: The Furukawa Nutrition and Health Study. Nutrition 2020, 78, 110962. [CrossRef] [PubMed]

27. Kudo, A.; Asahi, K.; Satoh, H.; Iseki, K.; Moriyama, T.; Yamagata, K.; Tsuruya, K.; Fujimoto, S.; Narita, I.; Konta, T.; et al. Fast eating is a strong risk factor for new-onset diabetes among the Japanese general population. Sci. Rep. 2019, 9, 8210. [CrossRef]

28. Cao, X.; Gu, Y.; Bian, S.; Zhang, Q.; Meng, G.; Liu, L.; Wu, H.; Zhang, S.; Wang, Y.; Zhang, T.; et al. Association between eating speed and newly diagnosed nonalcoholic fatty liver disease among the general population. Nutr. Res. 2020, 80, 78-88. [CrossRef]

29. Saito, Y.; Kajiyama, S.; Nitta, A.; Miyawaki, T.; Matsumoto, S.; Ozasa, N.; Kajiyama, S.; Hashimoto, Y.; Fukui, M.; Imai, S.; et al. Eating Fast Has a Significant Impact on Glycemic Excursion in Healthy Women: Randomized Controlled Cross-Over Trial. Nutrients 2020, 12, 2767. [CrossRef]

30. Nakamura, T.; Nakamura, Y.; Takashima, N.; Kadota, A.; Miura, K.; Ueshima, H.; Kita, Y. Eating Slowly Is Associated with Undernutrition among Community-Dwelling Adult Men and Older Adult Women. Nutrients 2021, 14, 54. [CrossRef]

31. Otsuka, R.; Tamakoshi, K.; Yatsuya, H.; Wada, K.; Matsushita, K.; OuYang, P.; Hotta, Y.; Takefuji, S.; Mitsuhashi, H.; Sugiura, K.; et al. Eating fast leads to insulin resistance: Findings in middle-aged Japanese men and women. Prev. Med. 2008, 46, 154-159. [PubMed] 
32. Robinson, E.; Almiron-Roig, E.; Rutters, F.; de Graaf, C.; Forde, C.G.; Tudur Smith, C.; Nolan, S.J.; Jebb, S.A. A systematic review and meta-analysis examining the effect of eating rate on energy intake and hunger. Am. J. Clin. Nutr. 2014, 100, 123-151. [CrossRef] [PubMed]

33. Sakata, T.; Yoshimatsu, H.; Masaki, T.; Tsuda, K. Anti-obesity actions of mastication driven by histamine neurons in rats. Exp. Biol. Med. (Maywood) 2003, 228, 1106-1110. [CrossRef] [PubMed]

34. Kokkinos, A.; le Roux, C.W.; Alexiadou, K.; Tentolouris, N.; Vincent, R.P.; Kyriaki, D.; Perrea, D.; Ghatei, M.A.; Bloom, S.R.; Katsilambros, N.; et al. Eating slowly increases the postprandial response of the anorexigenic gut hormones, peptide $Y Y$ and glucagon-like peptide-1. J. Clin. Endocrinol. Metab. 2010, 95, 333-337. [CrossRef]

35. Miyazawa, I.; Morino, K.; Fuse, K.; Kondo, K.; Ohi, A.; Nishida, K.; Kurihara, M.; Yasuhara, S.; Nakanishi, N.; Nishida, Y.; et al. Impact of obesity on underreporting of energy intake in type 2 diabetic patients: Clinical Evaluation of Energy Requirements in Patients with Diabetes Mellitus (CLEVER-DM) study. Clin. Nutr. ESPEN 2020, 39, 251-254. [CrossRef]

36. Shiraishi, A.; Wakabayashi, H.; Yoshimura, Y. Oral Management in Rehabilitation Medicine: Oral Frailty, Oral Sarcopenia, and Hospital-Associated Oral Problems. J. Nutr. Health Aging 2020, 24, 1094-1099. [CrossRef]

37. Tanaka, T.; Takahashi, K.; Hirano, H.; Kikutani, T.; Watanabe, Y.; Ohara, Y.; Furuya, H.; Tetsuo, T.; Akishita, M.; Iijima, K.; et al. Oral frailty as a risk factor for physical frailty and mortality in community-dwelling elderly. J. Gerontol. A Biol. Sci. Med. Sci. 2018, 73, 1661-1667.

38. Kaji, A.; Hashimoto, Y.; Kobayashi, Y.; Sakai, R.; Okamura, T.; Miki, A.; Hamaguchi, M.; Kuwahata, M.; Yamazaki, M.; Fukui, M. Sarcopenia is associated with tongue pressure in older patients with type 2 diabetes: A cross-sectional study of the KAMOGAWADM cohort study. Geriatr. Gerontol. Int. 2019, 19, 153-158. [CrossRef]

39. Kugimiya, Y.; Iwasaki, M.; Ohara, Y.; Motokawa, K.; Edahiro, A.; Shirobe, M.; Watanabe, Y.; Obuchi, S.; Kawai, H.; Fujiwara, Y.; et al. Relationship between oral hypofunction and sarcopenia in community-dwelling older adults: The otassha study. Int. J. Environ. Res. Public Health 2021, 18, 6666. [CrossRef]

40. Hatta, K.; Ikebe, K. Association between oral health and sarcopenia: A literature review. J. Prosthodont. Res. 2021, 65, 131-136. [CrossRef]

41. Chung, S.M.; Moon, J.S.; Chang, M.C. Prevalence of Sarcopenia and Its Association With Diabetes: A Meta-Analysis of CommunityDwelling Asian Population. Front. Med. 2021, 8, 681232. [CrossRef] [PubMed]

42. Kimura, T.; Okamura, T.; Iwai, K.; Hashimoto, Y.; Senmaru, T.; Ushigome, E.; Hamaguchi, M.; Asano, M.; Yamazaki, M.; Fukui, M. Japanese radio calisthenics prevents the reduction of skeletal muscle mass volume in people with type 2 diabetes. BMJ Open Diabetes Res. Care 2020, 8, e001027. [CrossRef] [PubMed]

43. Tamura, Y.; Omura, T.; Toyoshima, K.; Araki, A. Nutrition management in older adults with diabetes: A review on the importance of shifting prevention strategies from metabolic syndrome to frailty. Nutrients 2020, 12, 3367. [CrossRef] [PubMed] 